\title{
Miningo
}

http://dx.doi.org/10.1590/0370-44672020740090

\author{
André Carlos Silva ${ }^{1,3}$ \\ https://orcid.org/0000-0002-9760-0728 \\ Débora Nascimento Sousa ${ }^{2,4}$ \\ https://orcid.org/0000-0001-6639-6608 \\ Elenice Maria Schons Silva ${ }^{1,5}$ \\ https://orcid.org/0000-0003-1360-6450 \\ ${ }^{1}$ Universidade Federal de Catalão - UFCAT, \\ Laboratório de Modelamento e Pesquisa em \\ Processamento Mineral (LaMPPMin), Faculdade \\ de Engenharia, Catalão - Goiás - Brasil. \\ ${ }^{2}$ Instituto Federal Goiano - IFGoiano, \\ Departamento Mineração, Catalão - Goiás - Brasil. \\ E-mails: ${ }^{3}$ ancarsil@ufg.br, \\ ${ }^{4}$ debora.nascimento@ifgoiano.edu.br, \\ 5eschons@ufg.br
}

\section{Hematite and quartz microflotation using millet starch as depressant}

\begin{abstract}
Brazil is among the world's largest iron ore producers. The standard concentration method is reverse cationic flotation using amines, and their derivatives, such as quartz collector and corn (as either grits, flour, or starch) as the hematite depressant. Corn is considered cheap, abundant, and available all around the country. However, its demand has been abruptly increasing over the last few years, mainly due to the emerging of new attractive markets, such as ethanol production. In order to propose a feasible replacement for corn, hematite and quartz samples from the Brazilian Iron Quadrangle were tested in a modified Hallimond tube using millet starch as depressant for the first time (corn and sorghum starch were used as benchmark). Tests were carried out with four different depressant dosages and four different $\mathrm{pHs}$, all in triplicate. It was possible to reach quartz floatability above $98 \%$ and hematite depressability above $93 \%$ for millet and sorghum starches. This fundamental study shows that replacing corn with millet poses a real opportunity to reduce operational costs.
\end{abstract}

Keywords: flotation reagents; depressant; hematite; quartz; starches.

\section{Introduction}

The world's iron ore production has increased approximately 280 million tons from 2012 to 2017. According to Araujo et al. (2005), concentrates with iron content above $60 \%$ are required to fit the steel making industry requirements. The main concentration method for iron ore enrichment is the reverse cationic flotation, in which the iron ore, typically hematite, is depressed (Filippov et al., 2010; Ma et al., 2011) using starch, dextrin, sodium silicate, or CMC, inhibiting the adsorption of the collectors on the iron ore minerals surface (Bai et al., 2019). The gangue minerals, mainly composed of quartz, are recovered using amine-based collectors. Peres and Correa (1996) showed that minerals, such as iron oxides, have an affinity with starch and other polysaccharides, which facilitates their depression during the reverse cationic flotation. According to the Brazilian Mining Agency (ANM, 2018), approximately 265 Mtons of iron ore concentrate were produced in the Iron Quadrangle in 2016, consuming around 106 ktons of cornstarch (CS), considering an average dosage of $400 \mathrm{~g}$ of CS per ton of iron ore processed. CS is the standard depressant in Brazil, mainly due to its availability and market price (Araujo et 
al., 2005).

Starches from different botanical sources could be used as depressants as long as they are available in the market with acceptable price and sufficient volume to meet the mining company demands (Peres and Correa, 1996; Turrer and Peres, 2010; and Silva et al., 2019b).

Millets are diverse and broadly adapted crops. Pearl millet (Pennisetum glaucum), here addressed as millet, is an annual cespitose summer grass, with a high production of tillers and a vigorous regrowth after cutting or grazing. Showing a high drought tolerance, millet has

\section{Materials and methods}

\subsection{Mineral samples}

Mineral samples from the Brazilian Iron Quadrangle were used in this study. Sample preparation and characterization can be found elsewhere (Silva et al., been considered a rudimentary plant. No other cereal has a big harvest under similar climatic conditions, especially in high temperatures or in dry conditions. According to Graybosch and Baltensperger (2009), these features lead millet to become one of the main crops in semi-arid areas of Asia and Africa, where other major crops tend to fail. Millet flour has been used in the food industry to prepare cakes, biscuits, and porridge (Kulkarni et al., 2018). However, there is no record of its human consumption in Brazil, being cultivated as a fodder grass.

Research must be carried out to reduce, or to find, a suitable replacement for CS in the mineral industry. The present article shows for the first-time, the experimental results of hematite and quartz flotation using millet starch (MS) as depressant. CS and sorghum starch (SS) (Sorghum bicolor (L.) Moench) were used as benchmark. CS was used because it is the standard depressant in Brazil in a wide range of mineral flotation processes. SS, on the other hand, is a widely farmed crop cultivated in Brazil for animal feeding, with high economical and technical potential to be adopted in the mineral industry, as shown by Silva et al. (2019a).

\subsection{Starches extraction and characterization}

Pearl millet grains (type ADR 300 from ATTO Adriana Seeds) used in this study were provided by Fertigran, a company located in the city of Catalão, State of Goiás. Graniferous sorghum grains (type 1G100 from Dow AgroSciences) were farmed in Ipameri, Goiás, Brazil and provided by Agroceres. Straw residues and other impurities were removed by dry sieving. The starch extraction and characterization were performed as proposed by Silva et al. (2019a). Cargill supplied the CS samples (Amigel 12100). The starch granule morphology was analysed using SEM JSM-6610 from Jeol at Labmic/ UFG. Samples were fixed with carbon tape on aluminium supports and then

\subsection{Microflotation tests}

Figure 1 shows the experimental setup of the modified Hallimond tube, with internal volume of $320 \mathrm{~mL}$. The Stat-Ease DesignExpert 12 was used to plan and analyse the flotation results. An incomplete factorial design $4^{3}$ was adopted, with three independent variables ( $\mathrm{pH}$, depressant dosages and type) and four levels of each variable, except for the depressant type. Four pHs (9, 9.5, 10, and 10.5) were tested, as proposed in literature in close agreement with the industrial practice for hematite flotation, mineral recovery optimization, and preferred adsorption of the amine onto the quartz surface (Pinto et al., 1992, Santos and Oliveira, 2007, and Silva et al., 2019b). 2019b). According to the authors, the samples had a purity of around $97 \%$ and $95 \%$, for hematite (total $\mathrm{Fe}$ around $67.6 \%$ ) and quartz, respectively. The isoelectric

metallized with a thin gold layer (350 ̊). The starch density was measured by pycnometry and xylene as the liquid phase. The starch $\mathrm{pH}$ was measured according to the methodology proposed by the Adolfo Lutz Institute (1985).

Starches are water-insoluble, requiring a preparation stage prior to their use as a depressant, known as gelatinization (Liu et al., 2017). It is possible to perform the starch gelatinization by two procedures (thermal or alkaline). Alkaline gelatinization is normally performed using sodium hydroxide (Santiago-Ramos et al., 2017). The depressant gelatinization was performed by adding $2.7 \mathrm{~mL}$ of

Four depressant dosages were tested (5, $10,20$, and $40 \mathrm{mg} / \mathrm{L})$. In addition, blank tests (without depressant) were also carried out at the same four pHs. Flotigam EDA (an ether amine) manufactured by Clariant was used as collector in two different dosages: $20 \mathrm{mg} / \mathrm{L}$ for hematite and $5 \mathrm{mg} / \mathrm{L}$ for quartz, as proposed by Silva et al. (2019b). The authors discovered that the hematite floatability was, as expected, lower than the quartz floatability under the same operational conditions and in the absence of depressant. Therefore, a high collector dosage was used to produce similar floatability between the two minerals, allowing a better understanding of the depressant influence. point (IEP) for hematite was determined at $\mathrm{pH}$ 6.95. No IEP was determined in the tested $\mathrm{pH}$ range (3.5 to 12.5 ) for the quartz samples.

sodium hydroxide at $10 \%(\mathrm{w} / \mathrm{v})$ to a solution of $20.0 \mathrm{~mL}$ of distilled water and $1.0 \mathrm{~g}$ of starch. The solution was kept under magnetic stirring until complete gelatinization. The depressant $/ \mathrm{NaOH}$ ratio was adopted as proposed by Silva et al. (2017). The collector preparation consisted of a dilution of $1.0 \mathrm{~g}$ of it in distilled water to a total volume of 100 $\mathrm{mL}(1 \% \mathrm{w} / \mathrm{v})$ under magnetic stirring, as recommended by the manufacturer. The collector and depressant solutions were prepared daily to avoid any degradation of the reagents, especially starch retrogradation. Hydrochloric acid and sodium hydroxide, both at $1 \%$ solution, were used as $\mathrm{pH}$ modifiers.

The air pressure was kept at $10 \mathrm{psi}$ and the airflow at $40 \mathrm{~cm}^{3} / \mathrm{min}$, producing a superficial air velocity of $0.02 \mathrm{~cm} / \mathrm{s}$. These values were adopted in order to minimize the hydraulic entrainment (Guimarães Júnior et al., 2015). The mineral samples used, weighed $1.0 \mathrm{~g}$ and were wet sieved at $-149+105 \mu \mathrm{m}$ (or $-100+150 \#)$. Although this particular particle size is coarser than the industrial practice, hydraulic entrainment tests were performed by Guimarães Júnior et al. (2015) for both minerals and the lowest value was obtained at this granulometry. Even more, Ma et al. (2011) found good results working with iron ore samples from Brazil with $d_{80}$ of $129 \mu \mathrm{m}$ by reverse anionic flotation. 


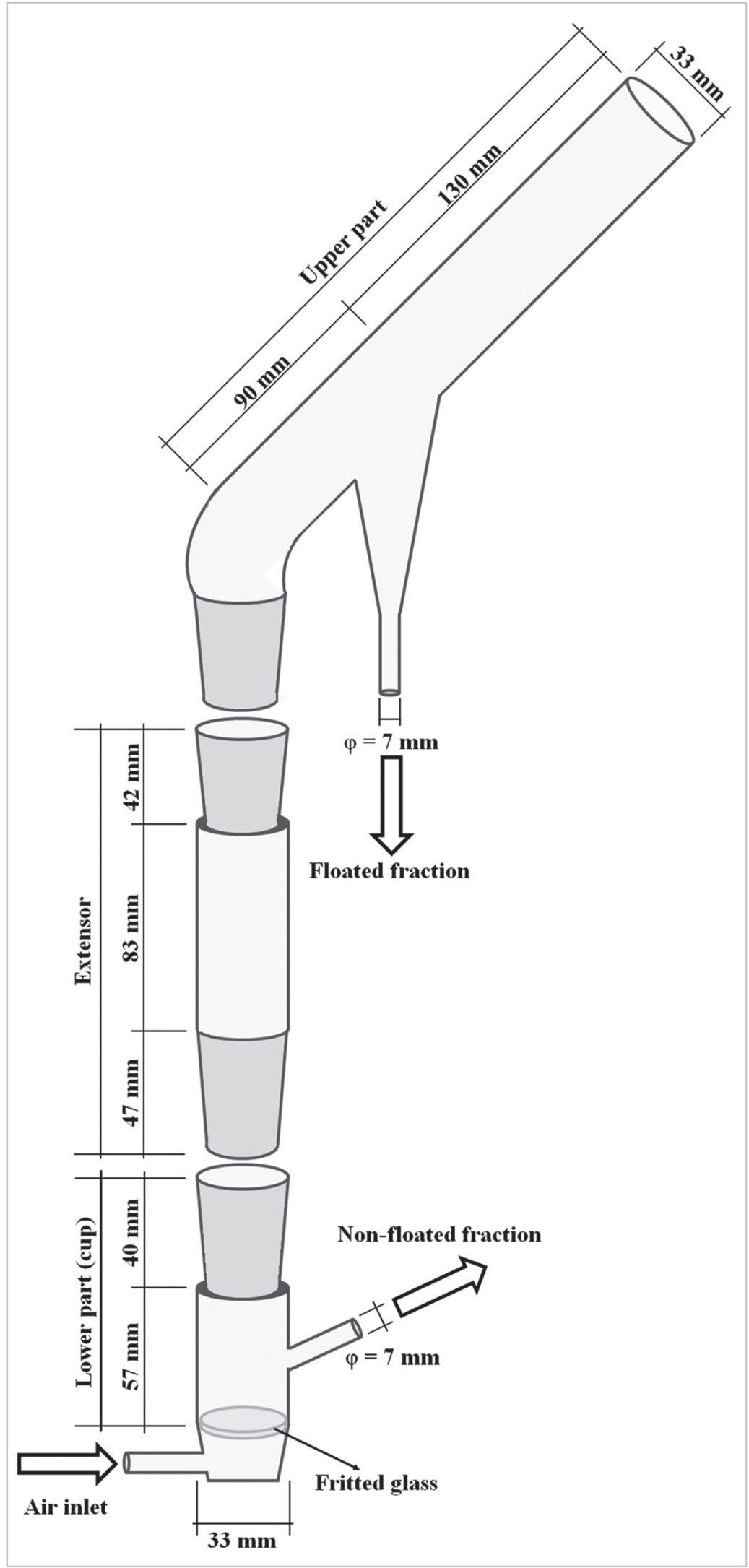

Figure 1 - Microflotation tests experimental setup.

The flotation was carried out for 1 minute after conditioning the starches for 5 minutes and the collector for 1 minute (Silva et al., 2019b; Kar et al.,
2013). All the flotation experiments were conducted at room temperature and in triplicate. Floated $\left(M_{f}\right)$ and depressed $\left(M_{d}\right)$ particles were vacuum filtered, oven

$$
\text { Quartz }_{\text {Floatability }}=100 \cdot \frac{M_{f}}{M_{f}+M_{d}}
$$

dried at $100^{\circ} \mathrm{C}$ for 24 hours, and weighted. The quartz floatability and hematite depressability were calculated as shown in Equation (1) and (2), respectively. 


\section{Results and discussion}

$$
\text { Hematite }_{\text {Depressability }}=100 \cdot \frac{M_{d}}{M_{f}+M_{d}}
$$

\subsection{Starches characterization}

MS extraction produced a white powder, with average yield of $38.6 \pm 0.45 \%$, almost $50 \%$ higher than SS $(25.82 \pm 4.08 \%)$. Figure 2 shows SEM/SEI images for the three starches.
Although the predominant shape of the starch granules was oval or semi-spherical, some grains with varied shapes could be seen. Watson and Eckhoff (2009) reported similar results for large sorghum granules with polygonal and spherical shapes. Regarding the grain texture, the starches had a smooth surface, with an occasional presence of superficial pores. No protein ribbons were found.
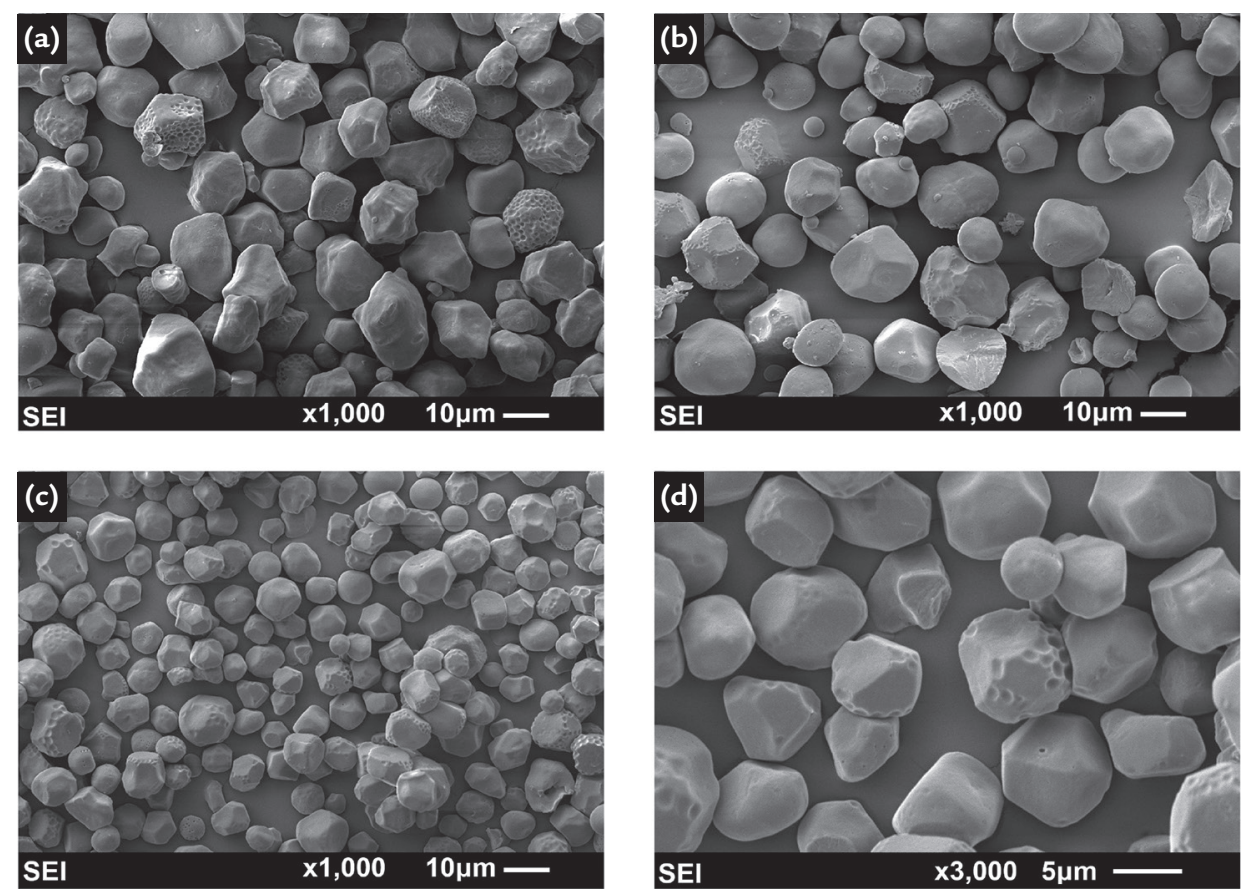

Figure 2 - SEM/SEI images for (a) CS, (b) SS, and (c) MS 1,000x magnification and (d) 3,000x magnification.

Table 1 shows the starch characterization results. Starches are mainly composed of Amyloses (AM) and Amylopectin (AP), in a ratio of approximately $1 / 3$ (Peres and Correa, 1996). This ratio was observed for MS
$(1 / 3.23 \pm 0.1)$ and SS (1/2.43 \pm 0.8$)$, but not for CS $(1 / 1.26 \pm 0.1)$, suggesting that these two starches have higher potential as a depressant than CS. Triacylglycerol (popularly designated as oil or lipid) present in the starch acts as an antifoaming agent, which impairs the flotation process if its content is higher than 1.5\% (Peres and Correa, 1996). All tested starches had lipid content below $1.5 \%$, with emphasis to MS $(0.12 \pm 0.05)$.

Table 1 - Depressants characterization.

\begin{tabular}{c|c|c|c}
\hline Botanical sources & Cornstarch & Millet starch & Sorghum starch \\
\hline Amylose (AM) (\%) & $38.73 \pm 0.8$ & $20.80 \pm 0.30$ & $25.46 \pm 0.8^{[\mathrm{a}]}$ \\
\hline AM molecular weight & 105 to $3 \times 10^{6[\mathrm{~b}]}$ & $1.6 \times 10^{6[\mathrm{c}]}$ & $1.1 \times 10^{7[\mathrm{~d}]}$ \\
\hline Amylopectin (AP) (\%) & $48.81 \pm 0.95$ & $67.10 \pm 0.62$ & $61.77 \pm 0.86$ \\
\hline AP molecular weight & 107 to $2 \times 10^{9[\mathrm{~b}]}$ & $1.3 \times 10^{7[\mathrm{c}]}$ & $3.0 \times 10^{8[\mathrm{~d}]}$ \\
\hline AM/AP & $1 / 1.26 \pm 0.1$ & $1 / 3.23 \pm 0.1$ & $1 / 2.43 \pm 0.8$ \\
\hline Lipids (\%) & $0.80 \pm 0.10$ & $0.12 \pm 0.05$ & $0.49 \pm 0.1^{[\mathrm{a}]}$ \\
\hline Proteins (\%) & $0.87 \pm 0.05$ & $1.00 \pm 0.05$ & $0.85 \pm 0.05^{[\mathrm{a}]}$ \\
\hline Ashes (\%) & $0.51 \pm 0.11$ & $0.10 \pm 0.03$ & $0.12 \pm 0.1^{[\mathrm{a}]}$ \\
\hline Solubility index (\%) & $2.35 \pm 0.42$ & $1.96 \pm 0.27$ & $1.43 \pm 0.2^{[\mathrm{a}]}$ \\
\hline Swelling power (g/g) & $7.93 \pm 0.25$ & $8.93 \pm 0.47$ & $9.88 \pm 0.2^{[\mathrm{a}]}$ \\
\hline Starch $\mathbf{~ p H}$ & $5.29 \pm 0.19$ & $6.52 \pm 0.08$ & $6.54 \pm 0.06$ \\
\hline Density $\left(\mathrm{g} / \mathrm{cm}^{3}\right)$ & $1.46 \pm 0.03$ & $1.39 \pm 0.04$ & $1.48 \pm 0.04$ \\
\hline
\end{tabular}

[a] Silva et al., 2019a; [b] BeMiller, 2018; [c] Madhusudhan and Tharanathan, 1996; [d] Matalanis et al., 2009. 
Additional study is required to understand the role of some starch components in mineral flotation, e.g. zein, the most abundant protein in corn, shows a depressing ability for hematite as strong as AP (Peres and Correa, 1996). MS protein content $(1.00 \pm 0.05)$ was approximately $15 \%$ higher than the other starches. MS and SS showed similar swelling power at

\subsection{Quartz microflotation results}

Figure 3 shows the average quartz floatability as a function of the depressant dosage for the tested $\mathrm{pHs}$. The highest results for quartz floatability were obtained for MS with dosages greater than or equal to $20 \mathrm{mg} / \mathrm{L}$. This result suggests that MS adsorption on the quartz surface is lower than the other two starches. In general, an high temperatures $\left(90{ }^{\circ} \mathrm{C}\right), 8.93 \pm 0.47$ $\mathrm{g} / \mathrm{g}$ and $9.88 \pm 0.2 \mathrm{~g} / \mathrm{g}$, respectively, and solubility index $(1.96 \pm 0.27 \%$ and 1.43 $\pm 0.2 \%$, respectively), in agreement with the results found by Tyl et al. (2018) for MS. According to Silva et al. (2019a), the solubility index is directly proportional to the protein amount. The swelling power, on the other hand, is directly proportional to the amount of $\mathrm{AM}$ and $\mathrm{AP}$, which partially explains the MS results. Starch densities were statistically similar and in agreement to the results available in literature (Silva et al., 2019a). It can be seen from the results that the starch $\mathrm{pH}$ values are close to neutrality, compatible with native starches that did not undergo any fermentation or modification process. increase in the depressant dosage resulted in a decrease in quartz floatability for CS and SS. It is possible to notice that quartz floatability was less susceptible to $\mathrm{pH}$ variation with MS. The average quartz floatability ranged from $42.53 \pm 3.19 \%$ to $90.90 \pm$ $1.77 \%$ with CS, while with MS ranged from $91.71 \pm 0.55 \%$ to $98.19 \pm 0.10 \%$, and from
$34.49 \pm 2.60 \%$ to $98.10 \pm 1.69 \%$ with SS . The highest average quartz floatability $(98.19$ $\pm 0.10 \%$ ) was obtained with $40 \mathrm{mg} / \mathrm{L}$ of MS at $\mathrm{pH} 10.5$. In the absence of the depressants the average quartz floatability ranged from $96.01 \pm 0.22(\mathrm{pH} 10)$ to $97.28 \pm 1.12 \%(\mathrm{pH}$ 9.5). The addition of the depressant reduced the quartz floatability, with a few exceptions.
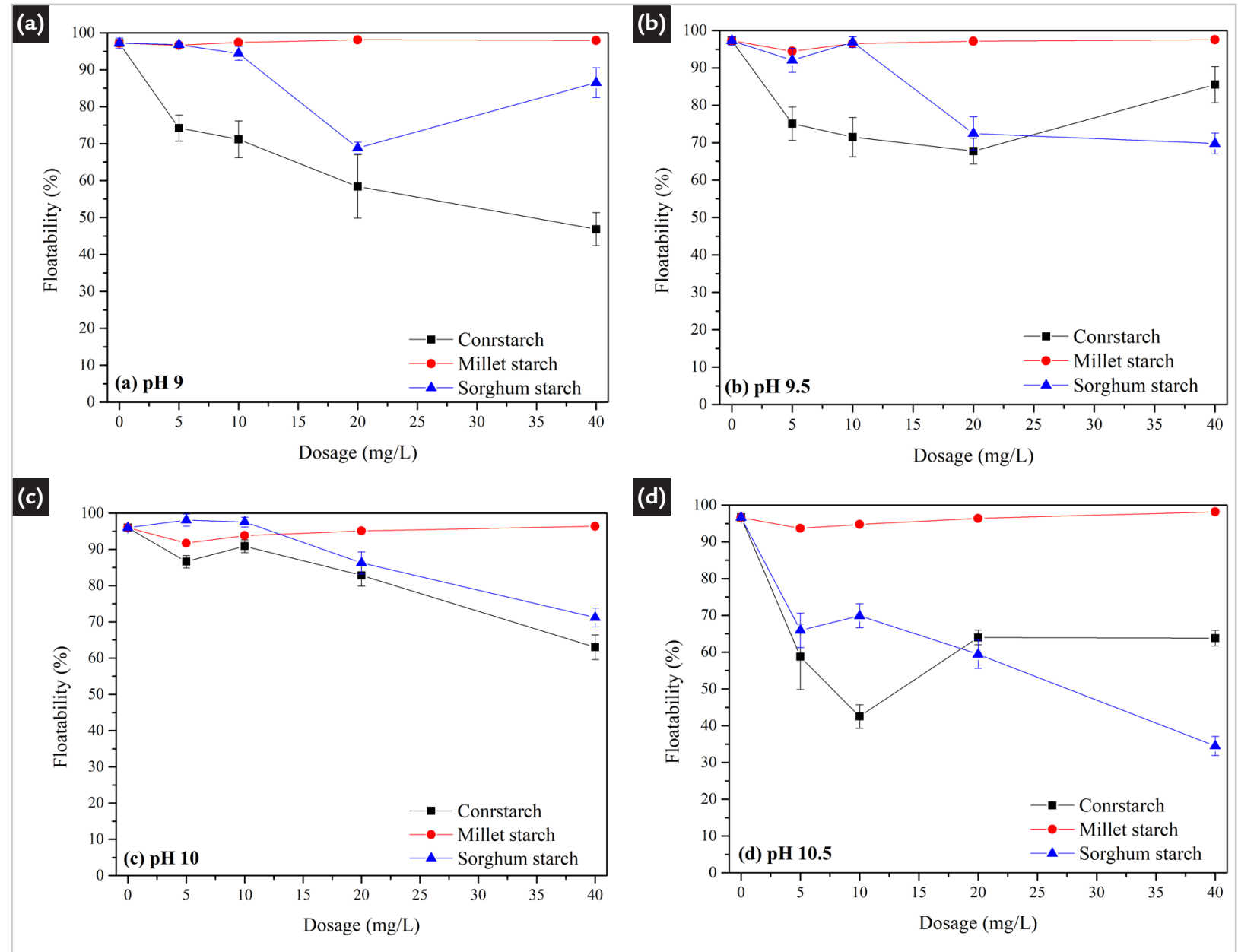

Figure 3 - Average quartz floatability as a function of the depressant dosage at four different pHs: (a) 9, (b) 9.5, (c) 10, and (d) 10.5.

Veloso et al. (2018) determined the isotherm adsorption of unmodified regular CS (73\% AP and $27 \%$ AM) by igneous iron ore samples. The authors found that at $\mathrm{pH} 10.5$, the depressant presented lower adsorption in the silicates (composed of albite, chamosite, diopside, microcline, quartz, and epidote), allowing them to be floated by the collectors. This behaviour was not seen in the carried-out tests. The average quartz floatability at $\mathrm{pH} 10.5$ dropped from $96.63 \pm 0.55 \%$ without CS to $42.53 \pm 3.19 \%$ with the addition of 10 $\mathrm{mg} / \mathrm{L}$, which was the lowest quartz floatability found at this $\mathrm{pH}$ for CS. In general, an increase in the depressant dosage pro- moted a decrease in the quartz floatability, indicating an interaction between them. Since in a reverse flotation the non-floated quartz will depress, contaminating the concentrate, it is expected that such decrease in the quartz floatability will promote a similar decrease in the hematite grade.

A cubic model was chosen to model 
the flotation results for quartz and for hematite (Tables 2 and 4, respectively). Figure 4 shows the 3D model for quartz flotation. The normality of the results was checked by plotting the normal probability versus studentized residuals (the residual is defined by difference between the observed and the predicted data). This plot indicates whether the residuals follow a normal distribution, in which case the points will follow a straight line. All the experimental results were approximate to the continuous line, which could be due to the absence of evident problems on design normality. Therefore, the adopted regression model was considered adequate (F-value of 30.85 and p-value $<0.0001$ ), with only a $0.01 \%$ chance that the F-value was due to noise as shown in Table 3 (model terms not significant are not shown). All three tested parameters $(\mathrm{pH}$, depressant dosage, and starch type) were significant for quartz floatability, as expected (Silva et al., 2019b; Pavlovic and Brandao, 2003). Therefore, it is safe to assume that the three parameters had influence in the quartz floatability. The first order interactions were significant for $\mathrm{pH}$ and the starch type, and depressant dosage and starch type, but not significant for $\mathrm{pH}$ and depressant dosage.

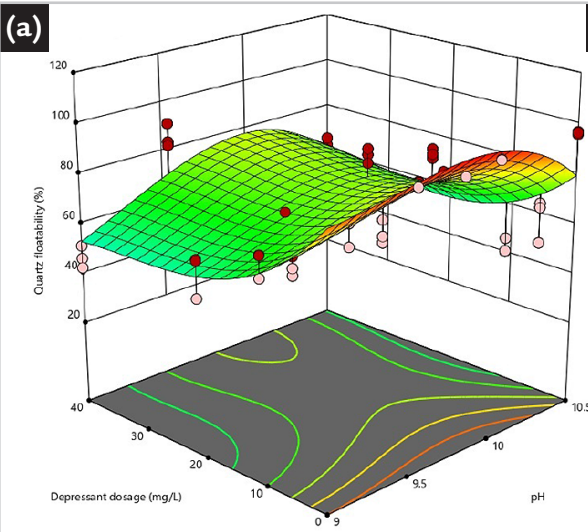

(b)

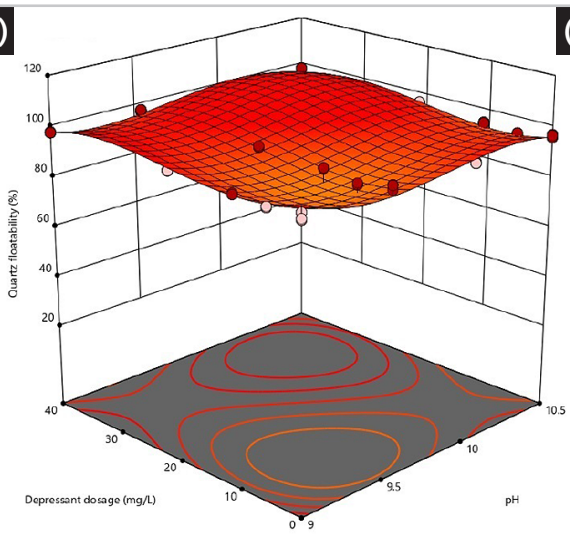

(c)

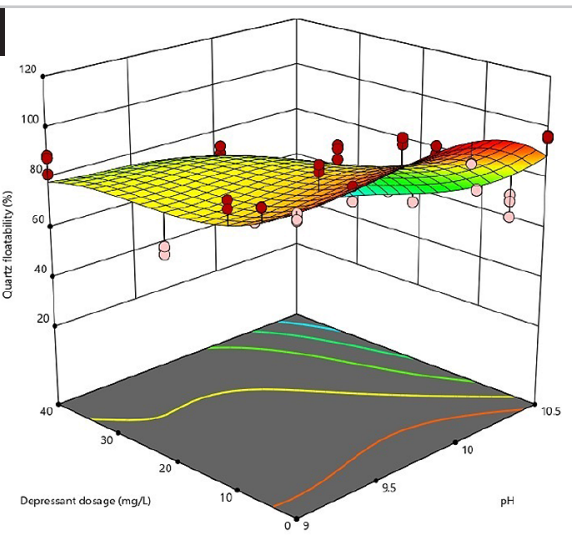

Figure 4 - Quartz response surface for (a) cornstarch, (b) millet starch, and (c) sorghum starch.

Table 2 - Models fit summary for quartz flotation results.

\begin{tabular}{c|c|c|c|c|c|}
\hline Model & Sequential p-value & Lack of Fit p-value & Adjusted $\mathbf{R}^{\mathbf{2}}$ & Predicted $\mathbf{R}^{\mathbf{2}}$ & Conclusions \\
\hline Linear & $<0.0001$ & $<0.0001$ & 0.4568 & 0.4342 & \\
\hline 2FI & $<0.0001$ & $<0.0001$ & 0.5763 & 0.5422 & \\
\hline Quadratic & $<0.0001$ & $<0.0001$ & 0.6700 & 0.6379 & Suggested \\
\hline Cubic & $<0.0001$ & $<0.0001$ & 0.7779 & 0.7447 & Aliased \\
\hline Quartic & $<0.0001$ & $<0.0001$ & 0.8668 & 0.8325 & \\
\hline
\end{tabular}

Table 3 - ANOVA for Cubic model for the quartz flotation. Model terms not significant are not shown.

\begin{tabular}{|c|c|c|c|c|c|}
\hline Source & Sum of squares & Degrees of freedom & Mean square & F-value & p-value \\
\hline Model & 39344.62 & 21 & 1873.55 & 30.85 & $<0.0001$ \\
\hline A-pH & 1675.04 & 1 & 1675.04 & 27.59 & $<0.0001$ \\
\hline B-Depressant dosage & 6852.19 & 1 & 6852.19 & 112.85 & $<0.0001$ \\
\hline C-Starch type & 14421.70 & 2 & 7210.85 & 118.75 & $<0.0001$ \\
\hline$A C$ & 1718.73 & 2 & 859.36 & 14.15 & $<0.0001$ \\
\hline $\mathrm{BC}$ & 4537.51 & 2 & 2268.75 & 37.36 & $<0.0001$ \\
\hline$A^{2}$ & 2859.78 & 1 & 2859.78 & 47.10 & $<0.0001$ \\
\hline $\mathrm{B}^{2}$ & 1673.97 & 1 & 1673.97 & 27.57 & $<0.0001$ \\
\hline$A B C$ & 1405.76 & 2 & 702.88 & 11.58 & $<0.0001$ \\
\hline $\mathrm{A}^{2} \mathrm{C}$ & 1950.10 & 2 & 975.05 & 16.06 & $<0.0001$ \\
\hline $\mathrm{B}^{2} \mathrm{C}$ & 1112.22 & 2 & 556.11 & 9.16 & 0.0002 \\
\hline$A^{3}$ & 608.03 & 1 & 608.03 & 10.01 & 0.0019 \\
\hline $\mathrm{B}^{3}$ & 316.32 & 1 & 316.32 & 5.21 & 0.0238 \\
\hline Residual & 9594.05 & 158 & 60.72 & & \\
\hline Lack of Fit & 8616.74 & 38 & 226.76 & 27.84 & $<0.0001$ \\
\hline Pure Error & 977.31 & 120 & 8.14 & & \\
\hline Cor. Total & 48938.67 & 179 & & & \\
\hline
\end{tabular}




\subsection{Hematite microflotation results}

The average hematite depressability as a function of the depressant dosage is shown in Figure 5. The hematite average depressability in the absence of the depressants ranged from $10.94 \pm 1.75 \%$ to $17.08 \pm 1.75 \%$ (at $\mathrm{pH}$ 10.5 and 9 , respectively). This result indicated a low hydraulic entrainment for the particle size distribution adopted in the experimental set up, which agrees with the results found by Guimarães Júnior et al. (2015). Average hematite depressability with CS ranged from $59.09 \pm 0.75 \%$ to $91.62 \pm 0.10 \%$, while with MS ranged from $84.53 \pm 1.28 \%$ to $96.58 \pm 0.14 \%$, and from $80.49 \pm 1.52 \%$ to $93.93 \pm 0.66 \%$ with SS. The highest average hematite depressability $(96.58 \pm 0.14 \%)$ was obtained with $40 \mathrm{mg} / \mathrm{L}$ of $\mathrm{MS}$ and $\mathrm{pH}$ 9. It is possible to notice that hematite flotability remained relatively stable for dosages greater than or equal to $10 \mathrm{mg} / \mathrm{L}$ for MS and SS.

Yang and Wang (2018) suggested that although AM is more readily adsorbed onto a hematite surface, AP plays a more important role than AM in determining the starch depressing ability in hematite flotation. However, the same authors affirm that when comparing AP from different sources, the one with more, longer branches would have stronger ability to depress hematite. This observation partially explains the SS results, but not the MS ones. One possible explanation for the MS results could be its AM/AP ratio, with AP content around 37\% and $9 \%$ higher than CS and SS, respectively. AP depressing ability is due to the presence of hydroxyl groups in the chemical structure of the starch (Pinto et al., 1992; Pavlovic and Brandao, 2003). According to Veloso et al. (2018), CS shows higher depressing ability for hematite at $\mathrm{pH} 10.5$, which is consistent with the results found with high dosages of the depressant (20 and $40 \mathrm{mg} / \mathrm{L}$ ). At these conditions, the average hematite depressability was $81.27 \pm 1.68 \%$ and $91.62 \pm 0.10 \%$, respectively.
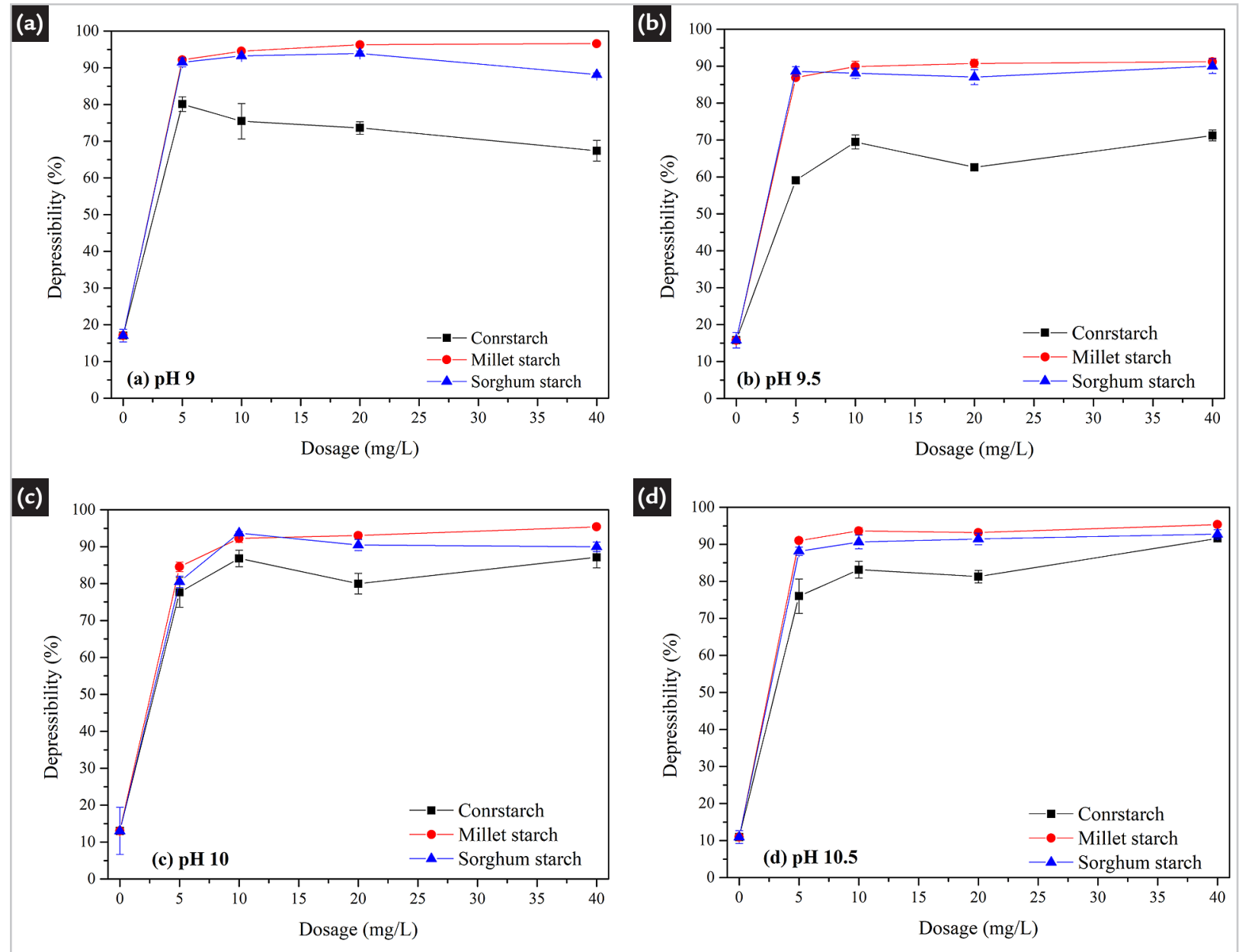

Figure 5 - Average hematite depressibility as a function of the depressant dosage at four different pHs: (a) 9, (b) 9.5, (c) 10, and (d) 10.5.

Figure 6 shows the 3D model for hematite flotation. Table 5 presents the ANOVA analysis for the hematite results. The model F-value of 122.59 implies the model is significant. There is only a $0.01 \%$ chance that an F-value this large could occur due to noise. However, the adoption of a cubic equation to model the experimental data could lead to the appearance of an inflection point and local minimum and maximum points. In this particular case, the local minimum point was observed for all tested starches around the dosage of $30 \mathrm{mg} / \mathrm{L}$. For the best knowledge of the authors, this point should not be taken into consideration, since this dosage was not tested. AbakaWood et al. (2018) performed flotation tests with Australian hematite and quartz in a standard $250 \mathrm{~cm}^{3}$ Denver microflotation cell. The authors suggested that the hematite flotation response is
$\mathrm{pH}$ dependent. Unexpectedly, for the found results, the $\mathrm{pH}$ was not significant, suggesting that the $\mathrm{pH}$ variation did not affect the hematite depressability for all tested starches. The first order interactions were significant for all three parameters, which indicates that the hematite depressability is not sensible to the $\mathrm{pH}$ variation alone, but it is sensible to $\mathrm{pH}$ variations associated with variations in any of the other two parameters. 

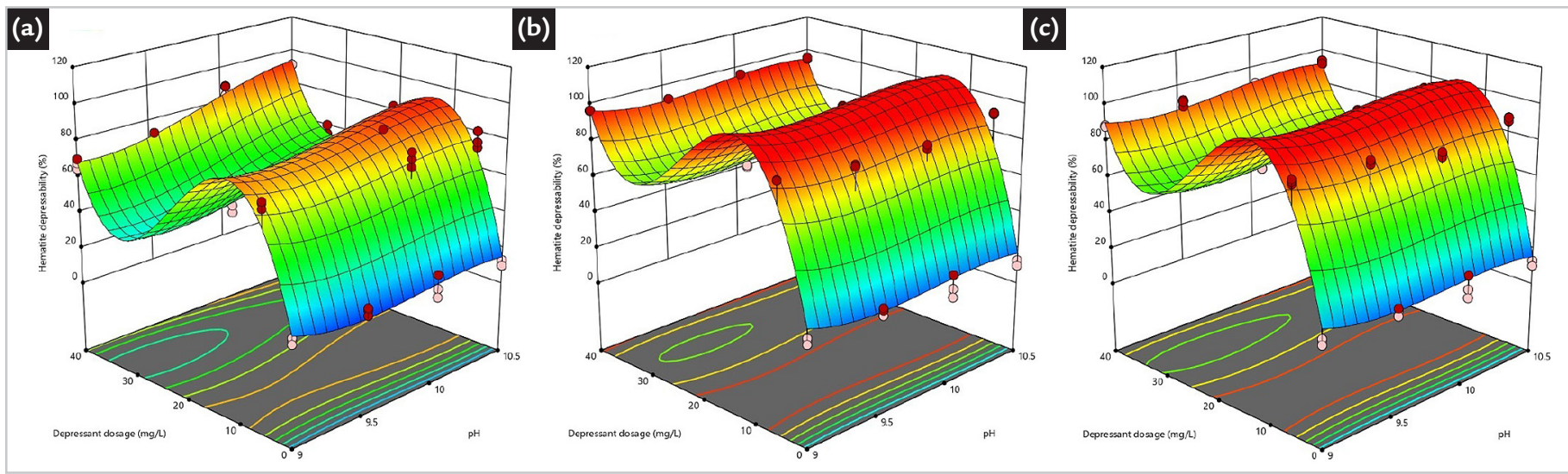

Figure 6 - Hematite response surface for (a) cornstarch, (b) millet starch, and (c) sorghum starch.

Table 4 - Models fit summary for hematite flotation results.

\begin{tabular}{|c|c|c|c|c|c|}
\hline Model & $\begin{array}{c}\text { Sequential } \\
\text { p-value }\end{array}$ & $\begin{array}{c}\text { Lack of Fit } \\
\text { p-value }\end{array}$ & Adjusted $\mathbf{R}^{2}$ & Predicted $\mathbf{R}^{2}$ & Conclusions \\
\hline Linear & $<0.0001$ & $<0.0001$ & 0.3151 & 0.2915 & \\
\hline $2 \mathrm{FI}$ & 0.7297 & $<0.0001$ & 0.3064 & 0.2612 & \\
\hline Quadratic & $<0.0001$ & $<0.0001$ & 0.6626 & 0.6421 & \\
\hline Cubic & $<0.0001$ & $<0.0001$ & 0.9345 & 0.9297 & Suggested \\
\hline Quartic & $<0.0001$ & $<0.0001$ & 0.9876 & 0.9856 & Aliased \\
\hline
\end{tabular}

Table 5 - ANOVA for Cubic model for the hematite flotation. Insignificant model terms are.

\begin{tabular}{|c|c|c|c|c|c|}
\hline Source & Sum of squares & Degrees of freedom & Mean square & F-value & p-value \\
\hline Model & $1.523 \mathrm{E}+05$ & 21 & 7254.38 & 122.59 & $<0.0001$ \\
\hline A-pH & 76.81 & 1 & 76.81 & 1.30 & 0.2563 \\
\hline B-Depressant dosage & 47721.68 & 1 & 47721.68 & 806.46 & $<0.0001$ \\
\hline C-Starch type & 5622.75 & 2 & 2811.37 & 47.51 & $<0.0001$ \\
\hline$A B$ & 668.14 & 1 & 668.14 & 11.29 & 0.0010 \\
\hline $\mathrm{AC}$ & 700.80 & 2 & 350.40 & 5.92 & 0.0033 \\
\hline$B C$ & 388.91 & 2 & 194.46 & 3.29 & 0.0400 \\
\hline$A^{2}$ & 341.99 & 1 & 341.99 & 5.78 & 0.0174 \\
\hline $\mathrm{B}^{2}$ & 54970.31 & 1 & 54970.31 & 928.95 & $<0.0001$ \\
\hline $\mathrm{ABC}$ & 367.93 & 2 & 183.97 & 3.11 & 0.0474 \\
\hline$A B^{2}$ & 31.82 & 1 & 31.82 & 0.5376 & 0.4645 \\
\hline $\mathrm{B}^{2} \mathrm{C}$ & 819.39 & 2 & 409.69 & 6.92 & 0.0013 \\
\hline$A^{3}$ & 393.63 & 1 & 393.63 & 6.65 & 0.0108 \\
\hline $\mathrm{B}^{3}$ & 40220.53 & 1 & 40220.53 & 679.69 & $<0.0001$ \\
\hline Residual & 9349.56 & 158 & 59.17 & & \\
\hline Lack of Fit & 8737.72 & 38 & 229.94 & 45.10 & $<0.0001$ \\
\hline Pure Error & 611.85 & 120 & 5.10 & & \\
\hline Cor. Total & $1.617 \mathrm{E}+05$ & 179 & & & \\
\hline
\end{tabular}

The found results suggest that starch adsorption occurs onto the surface of both minerals. However, at the tested $\mathrm{pH}$ range, the interaction between quartz and amine is stronger, making it difficult (maybe even preventing) the starch adsorption onto this mineral surface (Shrimali and
Miller, 2016). According to Lima et al. (2013), high amine dosages lead to the formation of clathrates, a compound in which molecules of one species occupy the empty spaces in the lattice of the other species, therefore resulting in the depression of hydrophobic minerals. The authors showed that high dosages of monoetheramine changed the quartz surface properties, resulting in an interaction between CS and the collector, reducing the quartz contact angle from $62^{\circ}$ to $43^{\circ}$, leading to quartz depression. This interaction between CS and amine could partially explain the results found with high dosages of this depressant. 


\section{Conclusions}

Millet starch showed high quartz floatability and hematite depressability, which could be explained due to its high amylopectin content $(67.10 \pm 0.62 \%)$. Millet starch shows a great potential to replace cornstarch as the standard hematite

\section{Acknowledgments}

The authors thank CNPq, CAPES, and FAPEG for the financial support, Modelling and Mineral Processing Re- depressant. With higher extraction yield $(38.6 \pm 0.45 \%)$ and high depressability results, the industrial adoption of millet starch could lead to operational costs reduction. On top of that, millet starch is less sensitive to $\mathrm{pH}$ variations, which could lead to better results when facing industrial fluctuations in the process. This was the first attempt to introduce millet starch as a novel, sustainable depressant in the mineral industry, in order to move away from corn.

\section{References}

search Lab (LaMPPMin), Laboratório Multiusuário de Microscopia de Alta Resolução (LabMic/UFG), Universidade
Federal de Catalão (UFCAT), and Instituto Federal Goiano (IFGoiano). Special thanks goes to Fertigran for the sample donation.

AACC METHODS. 08-21.01 Prediction of ash content in wheat flour: near-infrared method. In: AACC METHODS. Approved methods of analysis. 10th ed. St. Paul: Cereals \& Grains Association, 2000.

AACC METHODS. 61-03.01 Amylose content of milled rice. In: AACC METHODS. Approved methods of analysis. 11th ed. St. Paul: Cereals \& Grains Association, 2010.

ABAKA-WOOD, G. B.; ADDAI-MENSAH, J.; SKINNER, W. A study of selective flotation recovery of rare earth oxides from hematite and quartz using hydroxamic acid as a collector. Advanced Powder Technology, v. 29, n. 8, p. 1886-99, 2018.

ARAUJO, A. C.; VIANA, P. R. M.; PERES, A. E. C. Reagents in iron ores flotation. Minerals Engineering, v. 18, n. 2, p. 219-224, 2005.

BAI, S.; DING, Z.; FU, X.; LI, C.; LV, C.; WEN, S. Investigations on soluble starch as the depressant of hematite during flotation separation of apatite. Physicochemical Problems of Mineral Processing, v. 55, n. 1, p. 38-48, 2019.

BEMILLER, J. N. Starches: molecular and granular structures and properties. In: BEMILLER, J. N. Carbohydrate chemistry for food scientists. 3rd ed. London: Elsevier, 2018. cap. 6, p. 159-189.

BLIGH, E. G.; DYER, W. J. A rapid method of total lipid extraction and purification. Canadian Journal of Biochemistry and Physiology, v. 37, n. 8, p. 911-917, 1959.

BRADFORD, M. M. A rapid and sensitive method for the quantitation of microgram quantities of protein utilizing the principle of protein-dye binding. Analytical Biochemistry, v. 72, n. 1-2, p. 248-254, 1976.

BRASIL. Agência Nacional de Mineração. Anuário mineral brasileiro: principais substâncias metálicas. Brasília: ANM, 2018. $211 \mathrm{p}$.

FILIPPOV, L. O.; FILIPPOVA, I. V.; SEVEROV, V. V. The use of collectors mixture in the reverse cationic flotation of magnetite ore: The role of Fe-bearing silicates. Minerals Engineering, v. 23, n.2, p. 91-98, 2010.

GRAYBOSCH, R. A.; BALTENSPERGER, D. D. Evaluation of the waxy endosperm trait in proso millet (Panicum miliaceum). Plant Breeding, v. 128, p. 70-73, 2009.

GUIMARÃES JÚNIOR, P.; SILVA, A. C.; SILVA, E. M. S. Modelling the hydraulic entrainment phenomenon in microflotation. In: INTERNATIONAL SYMPOSIUM ON SUSTAINABLE MINERAL PROCESSING, 2nd, 2015, Antalya, Turkey. Proceedings [...]. Antalya: Flogen, 2015. p. 186-192.

INSTITUTO ALDOLFO LUTZ. Analytical standards of the Adolfo Lutz Institute: chemical and physical methods for food analysis. 3rd ed. São Paulo: IMESP, 1985. v. 1.

KAR, B.; SAHOO, H.; RATH, S. S.; DAS, B. Investigations on different starches as depressants for iron ore flotation. Minerals Engineering, v. 49, p. 1-6, 2013.

KULKARNI, D. B.; SAKHALE, B. K.; GIRI, N. A. A potential review on millet grain processing. International Journal of Nutritional Sciences, v. 3, n. 1, p. 1-8, 2018.

LEACH, H. W.; MCCOWEN, L. D.; SCHOCH, T. J. Swelling power and solubility of granular starches. Cereal Chemistry, v. 36, p. 534-544, 1959.

LIMA, N. P.; VALADÃO, G. E. S.; PERES, A. E. C. Effect of amine and starch dosages on the reverse cationic flotation of an iron ore. Minerals Engineering, v. 45, p. 180-184, 2013.

LIU, X.; XIAO, X.; LIU, P.; YU, L.; LI, M.; ZHOU, S. Shear degradation of corn starches with different amylose contents. Food Hydrocolloids, v. 66, p. 199-205, 2017.

MA, X.; MARQUES, M.; GONTIJO, C. Comparative studies of reverse cationic/anionic flotation of Vale iron ore. International Journal of Mineral Processing, v. 100, n. 3-4, p. 179-183, 2011.

MADHUSUDHAN, B.; THARANATHAN, R. N. Structural studies of linear and branched fractions of chickpea and finger millet starches. Carbohydrate Research, v. 284, n. 1, p. 101-109, 1996.

MATALANIS, A. M.; CAMPANELLA, O. H.; HAMAKER, B. R. Storage retrogradation behavior of sorghum, maize and rice starch pastes related to amylopectin fine structure. Journal of Cereal Science, v. 50, n. 1, p. 74-81, 2009. 
PAVLOVIC, S.; BRANDAO, P. R. G. Adsorption of starch, amylose, amylopectin and glucose monomer and their effect on the flotation of hematite and quartz. Minerals Engineering, v. 16, n. 11, p. 1117-1122, 2003.

PERES, A. E. C.; CORREA, M. I. Depression of iron oxides with corn starches. Minerals Engineering, v. 9, n. 12, p. 1227-1234, 1996.

PINTO, C. L. L.; ARAUJO, A. C. D.; PERES, A. E. C. The effect of starch, amylose and amylopectin on the depression of oxi-minerals. Minerals Engineering, v. 5, n. 3-5, p. 469-478, 1992.

SANTIAGO-RAMOS, D.; FIGUEROA-CÁRDENAS, J. D.; VÉLES-MEDINA, J. J.; MARISCAL-MORENO, R. M. Changes in the thermal and structural properties of maize starch during nixtamalization and tortilla-making processes as affected by grain hardness. Journal of Cereal Science, v. 74, p. 72-78, 2017.

SANTOS, I. D.; OLIVEIRA, J. F. Utilization of humic acid as a depressant for hematite in the reverse flotation of iron ore. Minerals Engineering, v. 20, n. 10, p. 1003-1007, 2007.

SHRIMALI, K.; MILLER, J. D. Polysaccharide depressants for the reverse flotation of iron ore. Transactions of the Indian Institute of Metals, v. 69, p. 83-95, 2016.

SILVA, A. C.; SILVA, E. M. C.; PERES, A. E. C.; SOUSA, D. N. Temperature influence in cornstarch gelatinization for froth flotation. REM - International Engineering Journal, v. 70, n. 2, p. 231-235, 2017.

SILVA, E. M. S.; PERES, A. E. C.; SILVA, A. C.; FLORÊNCIO, D. L.; CAIXETA, V. H. Sorghum starch as depressant in mineral flotation: part 2 - flotation tests. Journal of Materials Research and Technology, v. 8, n. 1, p. 403-410, 2019a.

SILVA, E. M. S.; PERES, A. E. C.; SILVA, A. C.; LEAL, M. C. D. M.; LIÃO, L. M.; ALMEIDA, V. O. Sorghum starch as depressant in mineral flotation: part 1 - extraction and characterization. Journal of Materials Research and Technology, v. 8, n. 1, p. 396-402, 2019b.

TURRER, H. D. G.; PERES, A. E. C. Investigation on alternative depressants for iron ore flotation. Minerals Engineering, v. 23, n. 11-13, p. 1066-69, 2010.

TYL, C.; MARTI, A.; HAYEK, J.; ANDERSON, J.; ISMAIL, B. P. Effect of growing location and variety on nutritional and functional properties of proso millet (Panicum miliaceum) grown as a double crop. Cereal Chemistry, v. 95, n. 2, p. 288-301, 2018.

VELOSO, C. H.; FILIPPOV, L. O.; FILIPPOVA, I. V.; OUVRARD, S.; ARAUJO, A. C. Investigation of the interaction mechanism of depressants in the reverse cationic flotation of complex iron ores. Minerals Engineering, v. 125, n. 15, p. 133-139, 2018.

WATSON, S. A.; ECKHOFF, S. R. Corn and sorghum starches: production. In: BEMILLER, J. N.; WHISTLER, R. L. (ed.). Starch: chemistry and technology. 3rd ed. London: Elsevier, 2009. cap. 9, p. 374-439.

YANG, S.; WANG, L. Structural and functional insights into starches as depressant for hematite flotation. Minerals Engineering, v. 124, p. 149-157, 2018.

Received: 13 August 2020 - Accepted: 06 October 2020.

All content of the journal, except where identified, is licensed under a Creative Commons attribution-type BY. 